\title{
Comparative analyses of DNA repeats and identification of a novel Fesreba centromeric element in fescues and ryegrasses
}

Jana Zwyrtková1, Alžběta Němečková1, Jana Čížková1, Kateřina Holušová1, Veronika Kapustová1, Radim Svačina', David Kopecký ${ }^{\prime}$, Bradley John Till ${ }^{2}$, Jaroslav Doležel ${ }^{1}$ and Eva Hřibová ${ }^{\prime *}$ (iD

\begin{abstract}
Background: Cultivated grasses are an important source of food for domestic animals worldwide. Increased knowledge of their genomes can speed up the development of new cultivars with better quality and greater resistance to biotic and abiotic stresses. The most widely grown grasses are tetraploid ryegrass species (Lolium) and diploid and hexaploid fescue species (Festuca). In this work, we characterized repetitive DNA sequences and their contribution to genome size in five fescue and two ryegrass species as well as one fescue and two ryegrass cultivars.

Results: Partial genome sequences produced by Illumina sequencing technology were used for genome-wide comparative analyses with the RepeatExplorer pipeline. Retrotransposons were the most abundant repeat type in all seven grass species. The Athila element of the Ty3/gypsy family showed the most striking differences in copy number between fescues and ryegrasses. The sequence data enabled the assembly of the long terminal repeat (LTR) element Fesreba, which is highly enriched in centromeric and (peri)centromeric regions in all species. A combination of fluorescence in situ hybridization (FISH) with a probe specific to the Fesreba element and immunostaining with centromeric histone $\mathrm{H3}(\mathrm{CENH} 3)$ antibody showed their co-localization and indicated a possible role of Fesreba in centromere function.

Conclusions: Comparative repeatome analyses in a set of fescues and ryegrasses provided new insights into their genome organization and divergence, including the assembly of the LTR element Fesreba. A new LTR element Fesreba was identified and found in abundance in centromeric regions of the fescues and ryegrasses. It may play a role in the function of their centromeres.
\end{abstract}

Keywords: Festuca, Lolium, Illumina sequencing, Repetitive DNA, Centromere organization

\footnotetext{
* Correspondence: hribova@ueb.cas.cz

'Institute of Experimental Botany, Czech Academy of Sciences, Centre of the Region Haná for Biotechnological and Agricultural Research, Šlechtitelư 31, CZ-77900 Olomouc, Czech Republic

Full list of author information is available at the end of the article
}

(c) The Author(s). 2020 Open Access This article is licensed under a Creative Commons Attribution 4.0 International License, which permits use, sharing, adaptation, distribution and reproduction in any medium or format, as long as you give appropriate credit to the original author(s) and the source, provide a link to the Creative Commons licence, and indicate if changes were made. The images or other third party material in this article are included in the article's Creative Commons licence, unless indicated otherwise in a credit line to the material. If material is not included in the article's Creative Commons licence and your intended use is not permitted by statutory regulation or exceeds the permitted use, you will need to obtain permission directly from the copyright holder. To view a copy of this licence, visit http://creativecommons.org/licenses/by/4.0/ The Creative Commons Public Domain Dedication waiver (http://creativecommons.org/publicdomain/zero/1.0/) applies to the data made available in this article, unless otherwise stated in a credit line to the data. 


\section{Background}

Grasses (Poaceae) are an important source of food for domestic animals worldwide and perform important ecological and environmental functions. The tribe Poeae is the largest tribe in family Poaceae, and species from its largest subtribe, Loliinae, grow in a range of habitats, including wetlands, dry areas, and regions with cold and temperate climates; some are even well adapted to the extreme conditions of mountain, arctic, and subAntarctic regions [1]. The subtribe Loliinae comprises a cosmopolitan genus Festuca and its satellite genera [2, 3]. Festuca is the largest genus of the family Poaceae, containing more than 600 species, and Torrecilla and Catalán [4] discriminated its two main evolutionary lines: broad leaved and fine leaved (Fig. 1). Broad-leaved Festuca species (hereafter "fescues") include the subgenus Schedonorus, which gave rise to Lolium species (hereafter "ryegrasses"), a sister group of fescues (Fig. 1) [1]. The evolution of grasses, including Loliinae, has been accompanied by frequent polyploidization and hybridization events, and about $70 \%$ of grass species are polyploid [6]. The species of Loliinae have large genomes ranging from $2.6 \mathrm{Gbp} / 1 \mathrm{C}$ to $11.8 \mathrm{Gbp} / 1 \mathrm{C}[7,8]$.

This study focuses on species from the subgenus Schedonorus, a complex of species with various ploidy levels $[7,9]$ that includes important species widely used for forage and turf. Although some Schedonorus species are diploid, such as Festuca pratensis Huds. $(2 \mathrm{n}=2 \mathrm{x}=$ 14) and Lolium multiflorum Lam. $(2 \mathrm{n}=2 \mathrm{x}=14)$ and $L$. perenne L. $(2 \mathrm{n}=2 \mathrm{x}=14)$, the majority of species are allopolyploid [10, 11], including tetraploids F. glaucescens Boiss. $(2 \mathrm{n}=4 \mathrm{x}=28)$ and F. mairei St. Yves $(2 \mathrm{n}=4 \mathrm{x}=28)$ and hexaploids $F$. arundinacea Schreb. $(2 \mathrm{n}=6 \mathrm{x}=42)$ and $F$. gigantea (L.) Vill. $(2 \mathrm{n}=6 \mathrm{x}=42)[3,11]$. Fescues are more tolerant than ryegrasses of abiotic stresses, provide high-quality forage for livestock, and are grown especially for turf purposes. In contrast, ryegrasses are characterized by high yield and excellent nutritional value and are mostly cultivated as pasture. Artificial intergeneric hybrids of fescue and ryegrass species have been developed to combine the most favorable characteristics of both genera [12-14].

Although fescues and ryegrasses have been intensively studied, their evolution and the origin of most polyploid representatives remain obscure $[11,15,16]$. Like in other species with large genomes, the nuclear genomes of fescues and ryegrasses include a large number and variety of repetitive DNA sequences $[17,18]$. Their amplification in the genome, accompanied by interspecific hybridization and polyploidization, has expanded the genome size [19-24]. However, these processes have likely been counterbalanced by recombination-based mechanisms that have removed substantial parts of nuclear genomes [25-27].

Repetitive DNA elements may play different roles in a nuclear genome. Tandem organized ribosomal RNA genes and telomeric sequences are the key components of nucleolar organizing regions and chromosome

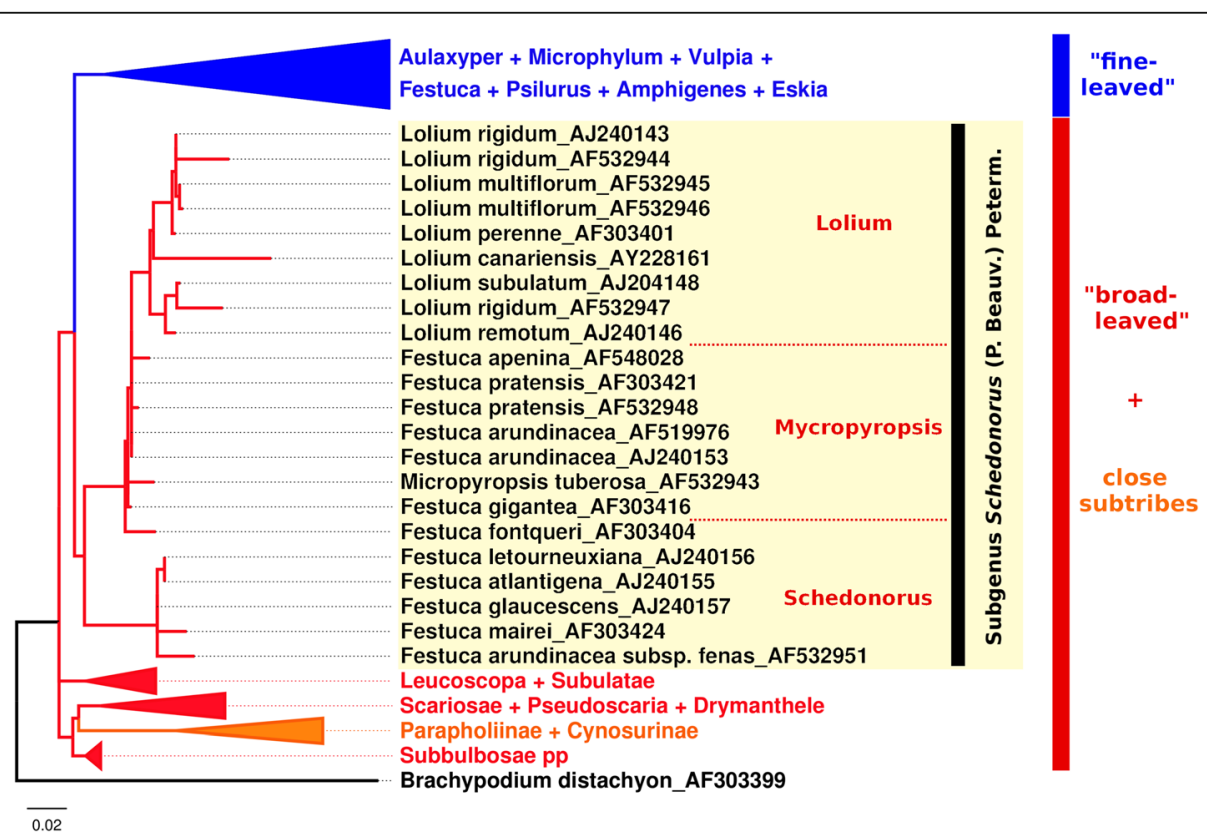

Fig. 1 Phylogenetic tree of Loliinae subtribe. Phylogeny of subtribe Loliinae with Brachypodium distachyon was used as an outgroup. The tree was constructed from ITS sequence regions of Loliinae species and B. distachyon with PhyML implemented in SeaView [5]. Detailed phylogeny of subgenus Schedonorus is depicted and shows the relationships of fescue and ryegrass species in this lineage (highlighted in light yellow) 
termini, respectively. Centromeric regions in Arabidopsis, Brachypodium, rice, and maize are partly formed from specific satellite DNAs with $\sim 130 \mathrm{bp}$ long units [28-31], whereas in other plant species, including cereals, these regions are formed by large blocks of Ty3/gypsy retrotransposons containing chromodomain [29, 32-34]. In F. pratensis, a putative long terminal repeat (LTR) element localizing preferentially to centromeric regions has been identified [35]. In addition to elucidating the molecular organization of chromosome domains, characterization of repetitive parts of nuclear genomes helps in the development of cytogenetic markers $[21,35,36]$. Repetitive DNA sequences are also used extensively to study genetic diversity and processes of genome evolution and speciation [37-40].

The main goal of the present work was to elucidate the repetitive landscape and its impact on genome size and genome divergence in closely related land grasses, including natural polyploid species. We characterized repetitive DNA sequences in the nuclear genomes of 10 representatives of fescues and ryegrasses. We performed global analyses of repetitive DNA sequences and characterized their abundance and variability after partial Illumina sequencing. Moreover, we characterized and assembled the DNA sequence of an LTR element that was highly enriched in centromeric and (peri)centromeric chromosome regions in all 10 genotypes. Colocalization of the centromere-specific histone $\mathrm{H} 3$ variant CENH3 with the LTR element indicated its role in centromere function.

\section{Results}

\section{Genome size estimation}

Flow cytometric analysis of propidium iodide-stained nuclei was conducted to estimate nuclear DNA content (Fig. 2). Because of the large differences in genome size between the species analyzed, two internal reference standards were used: Pisum sativum cv. Ctirad $(2 \mathrm{C}=$ 9.09 pg DNA) [41] and Secale cereale cv. Dankovske $(2 \mathrm{C}=16.19 \mathrm{pg}$ DNA $)$ [41]. All histograms of relative DNA content represented two dominant peaks corresponding to G1 nuclei of the sample and the standard. The 2C nuclear DNA content thus determined ranged from $5.32 \mathrm{pg}$ in L. multiflorum to $20.17 \mathrm{pg}$ in F. gigantea. The monoploid genome (1Cx) ranged in size from 2.43 in F. mairei to $3.36 \mathrm{pg}$ in F. gigantea (Table 1). The remaining representatives of fescues and ryegrasses had similar 1Cx sizes $(\sim 2.7 \mathrm{~Gb})$.

\section{Repeat composition and comparative analyses of repetitive DNA sequences}

Interspecific comparisons, reconstruction, and quantification of major repeat families were performed with the
RepeatExplorer pipeline [42]. The process, which involved grouping orthologous repeat families from all analyzed species in the same cluster, facilitated the assembly, identification, and quantification of individual repeat elements.

In all accessions, LTR retroelements were the most abundant component of the nuclear genome (Table 2, Fig. 3). Ty3/gypsy elements were more than 4 times more abundant than Ty1/copia retrotransposons (Table 2 ). The biggest difference in copy number between fescues and ryegrasses was for an LTR element from the Athila clade. Whereas the nuclear genomes of both Lolium species were enriched for the element, which accounted for $\sim 25-30 \%$ of their genomes, the orthologous Athila element accounted for only $\sim 5-7 \%$ of the nuclear genomes of fescues (Table 2). A relatively large part of the genomes was represented by unclassified LTR sequences, which indicates a high frequency of unique LTR sequences. DNA transposons and long interspersed nuclear element (LINE) elements were found in low copy numbers, and tandem repeats accounted for $1.5 \%$ to more than $8 \%$ of the genome sequences (Table 2, Fig. 3).

Comparative analyses with RepeatExplorer showed that most clusters of orthologous repeat families contained reads from all accessions and that a large number of similar sequences were present in fescues and ryegrasses. Among the fescues, F. mairei and F. glaucescens showed the lowest similarity in DNA repeats. The composition as well as the abundance of DNA repeats in ryegrasses were highly conserved. Tandem organized repeats were the most diverged elements among the fescues and ryegrasses studied, and some of the repeats were species specific (Fig. 4, Additional file 1: Table S1). In addition to tandem repeats, some small sequence clusters contained reads from only a few species. Species-specific variants of the majority of repetitive elements within and between fescues and ryegrasses were identified only after detailed analyses of individual repeat clusters with SeqGrapheR (Fig. 5a-c). Detailed analyses revealed the presence of species-specific DNA contigs, which may be used to develop molecular and cytogenetic markers.

To confirm the differences determined in silico, we analyzed selected repetitive DNA elements using Southern hybridization. We designed specific probes for those DNA repeats that seemed to have species-specific variants. A probe for the Ty3/gypsy Athila element that was reconstructed in cluster CL1 and showed the largest copy number variation between fescues and ryegrasses (Table 2) gave strong hybridization signals on genomic DNA from ryegrasses but no or weak signals on DNA from fescues (Fig. 5d). Similarly, a probe for the Ty3/ gypsy Athila element that was reconstructed in cluster 


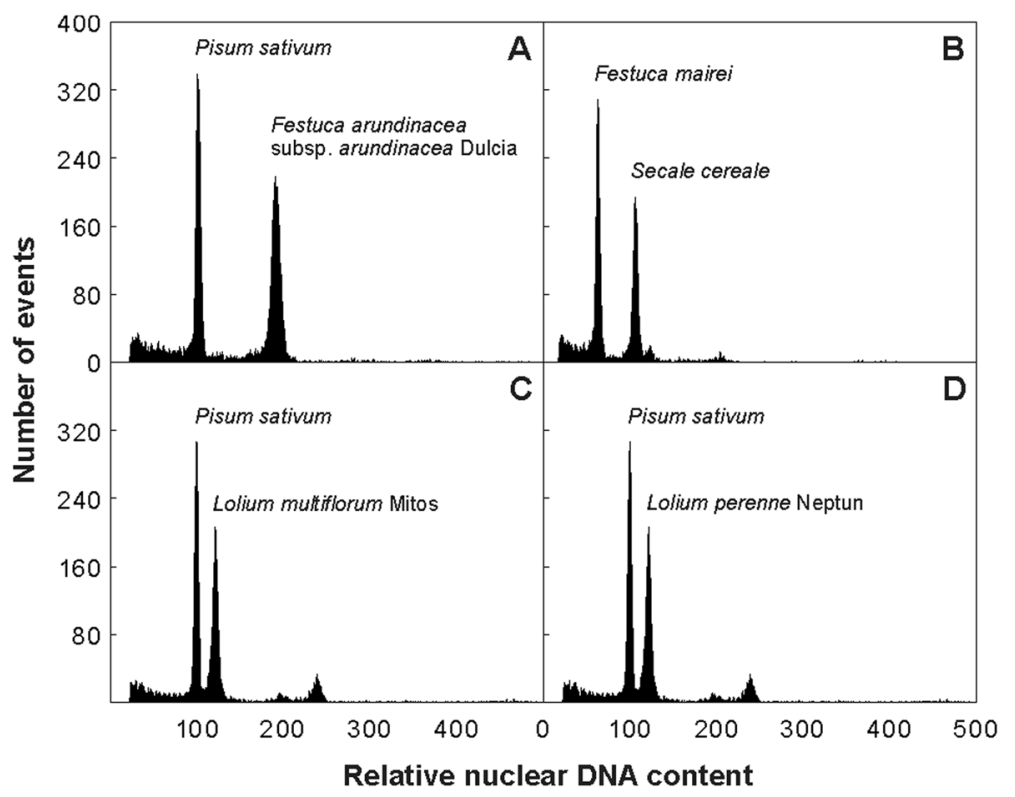

Fig. 2 Estimation of nuclear genome size. Histograms of propidium iodide-stained nuclei corresponding to relative nuclear DNA content obtained after flow cytometric analyses of F. arundinacea subsp. arundinacea (a), F. mairei (b), Lolium multiflorum cv. Mitos (c), and L. perenne cv. Neptun (d). Pisum sativum cv. Ctirad $(2 \mathrm{C}=9.09 \mathrm{pg})$ and Secale cereale cv. Dankovske $(2 \mathrm{C}=16.19 \mathrm{pg})$, respectively, were used as internal reference standards. The ratio of relative G1 peak positions was used to calculate DNA amounts of the fescue and ryegrass accessions

CL38 and contained mostly Festuca sequence reads (Fig. $5 \mathrm{~b})$ provided strong visible signals only with fescue genomic DNA (Fig. 5e). Finally, Southern hybridization was performed with a probe for the Ty3/gypsy Ogre-Tat retrotransposon, identified in cluster CL20. The probe, which was designed from contigs representing fescues (Fig. 5c), provided strong hybridization signals on all fescues analyzed and low intensity signals on ryegrasses (Fig. 5f). In general, the signal intensities obtained after Southern hybridization corresponded to the copy numbers identified in silico.

\section{Centromere composition}

Partial genome sequence data obtained using Illumina sequencing technology made it possible to reconstruct nearly complete centromeric LTR elements in all 10 accessions of fescues and ryegrasses. Detailed characterization of the element called Fesreba confirmed that it belongs to the Ty3/gypsy Chromoviridae lineage. Phylogenetic analyses of its reverse transcriptase (RT) domain showed a close relationship with the Cereba element (Fig. 6), which was identified earlier in barley (Hordeum vulgare) [43].

Southern hybridization with a probe for the RT domain of Fesreba and a probe for its LTR region [35] showed their presence in all fescues and ryegrasses included in this work (Additional file 2: Fig. S1). Similar hybridization patterns indicated sequence conservation between Fesreba repetitive DNA elements in these species. The results were supported by in silico data, which showed high similarity at the DNA sequence level (most abundant copies of Fesreba shared at least 92\% similarity at the DNA level within and between fescues and ryegrasses) but lower abundance in ryegrasses. To confirm the differences in Fesreba copy number, we performed quantification for the RT domain and LTR sequence using droplet digital polymerase chain reaction (ddPCR). The results confirmed a two-fold higher copy number of Fesreba in fescues compared to ryegrasses (Additional file 3: Table S2). The assay also showed that the majority of genotypes analyzed contained 5 to 50 times more copies of the LTR region of Fesreba than its coding region (Additional file 3: Table S2).

To confirm preferential localization of Fesreba to centromeric chromosome regions, we conducted fluorescence in situ hybridization (FISH) on mitotic metaphase plates with probes derived from its RT domain and LTR region. In all fescues and ryegrasses, both probes localized preferentially to centromeric regions of all chromosomes (Fig. 7). Whereas the hybridization signals of the RT domain were observed almost exclusively in centromeric regions, a probe derived from the noncoding LTR region resulted in stronger signals in centromeric and/or pericentromeric regions and weak signals along the chromosomal arms, as shown previously in $F$. pratensis [35]. Weak signals of the LTR part of Fesreba 
Table 1 Flow cytometric estimation of nuclear genome size

\begin{tabular}{|c|c|c|c|c|c|c|c|}
\hline \multirow[t]{2}{*}{ Species } & \multirow{2}{*}{$\begin{array}{l}\text { Accession } \\
\text { name }\end{array}$} & \multirow[t]{2}{*}{ Code } & \multirow[t]{2}{*}{ Ploidy level } & \multicolumn{2}{|c|}{ 2C nuclear DNA content } & \multicolumn{2}{|c|}{ Monoploid genome size (1Cx) } \\
\hline & & & & Mean [pg] & $\pm S D$ & {$[p g]$} & [Mbp] \\
\hline Festuca pratensis & Fure & FPF & $2 n=2 x=14$ & 6.4 & 0.04 & 3.2 & 3130 \\
\hline Festuca pratensis & Westa & FPW & $2 n=4 x=28$ & 12.79 & 0.09 & 3.2 & 3127 \\
\hline Festuca arundinacea ssp. arundinacea & Dulcia & FAR & $2 n=6 x=42$ & 16.85 & 0.24 & 2.81 & 2747 \\
\hline Festuca arundinacea ssp. glaucescens & - & FGL & $2 n=4 x=28$ & 10.79 & 0.07 & 2.7 & 2638 \\
\hline Festuca gigantea & GR 11759 & $\mathrm{FGl}$ & $2 n=6 x=42$ & 20.17 & 0.14 & 3.36 & 3288 \\
\hline Festuca mairei & GR 610941 & FMA & $2 n=4 x=28$ & 9.73 & 0.05 & 2.43 & 2379 \\
\hline Lolium multiflorum & $\operatorname{Lm} 2$ & LM2 & $2 n=2 x=14$ & 5.32 & 0.03 & 2.66 & 2601 \\
\hline Lolium multiflorum & Mitos & LMM & $2 n=4 x=28$ & 11.13 & 0.05 & 2.78 & 2721 \\
\hline Lolium perenne & GR 3320 & LP2 & $2 n=2 x=14$ & 5.54 & 0.03 & 2.77 & 2709 \\
\hline Lolium perenne & Neptun & LPN & $2 n=4 x=28$ & 10.94 & 0.15 & 2.74 & 2675 \\
\hline
\end{tabular}

in distal parts of chromosomes indicate the presence of unique LTRs spread over the genome and correspond to a higher copy number of the LTR non-coding part of Fesreba compared to its coding sequence.

In addition to the fescues and ryegrasses included in this study, FISH was performed with the same probes on mitotic metaphase plates from related grass species, oat, barley, rye, bread wheat, and Aegilops tauschii. High homology of the RT coding domain resulted in successful in situ localization in all species. However, the probe specific to the LTR region of Fesreba provided visible signals only in A. sativa (Additional file 4: Fig. S2).
Finally, immunostaining with the centromere-specific histone H3 variant CENH3 [44] in combination with FISH with probes for the RT domain and LTR region of Fesreba resulted in overlapping signals in all fescues and ryegrasses studied (Fig. 8, Additional file 5: Fig. S3).

\section{Discussion}

Because of genome shock, the $1 \mathrm{Cx}$ size of polyploid species is often, but not always, lower than that of their progenitors $[25,45]$. In this study, we performed comparative analyses of repeatomes and analyzed the impact of DNA repeats on genome size in a set of Festuca and

Table 2 Proportion of repetitive DNA sequences identified de novo

\begin{tabular}{|c|c|c|c|c|c|c|c|c|c|c|c|c|}
\hline \multirow[t]{2}{*}{ Repeat } & & \multirow[t]{2}{*}{ Lineage/class } & \multicolumn{10}{|c|}{ Proportion of repeat in monoploid genomes [\%] } \\
\hline & & & FPF & FPW & FAR & $\mathrm{FGl}$ & FGL & FMA & LM2 & LMM & LP2 & LPN \\
\hline \multirow[t]{11}{*}{ LTR retroelements } & Ty1/Copia & Maximus-SIRE & 1.72 & 1.65 & 1.69 & 1.78 & 1.84 & 1.93 & 0.89 & 0.87 & 1.16 & 1.25 \\
\hline & & Angela & 4.43 & 4.53 & 3.33 & 4.86 & 2.83 & 2.54 & 3.63 & 3.32 & 4.52 & 4.13 \\
\hline & & TAR (Tont) & 0.3 & 0.27 & 0.28 & 0.30 & 0.31 & 0.34 & 0.28 & 0.25 & 0.24 & 0.25 \\
\hline & & Tork (Tnt) & 0.05 & 0.04 & 0.05 & 0.05 & 0.05 & 0.06 & 0.07 & 0.07 & 0.08 & 0.07 \\
\hline & & Ale (Hopscotch) & 0.1 & 0.07 & 0.07 & 0.07 & 0.04 & 0.03 & 0.22 & 0.22 & 0.14 & 0.14 \\
\hline & & Ivana-Oryoco & 0.05 & 0.05 & 0.03 & 0.07 & 0.02 & 0.02 & 0.03 & 0.02 & 0.01 & 0.02 \\
\hline & & Total Ty1/Copia & 6.65 & 6.61 & 5.45 & 7.13 & 5.09 & 4.92 & 5.12 & 4.75 & 6.15 & 5.86 \\
\hline & Tyз/Gypsy & Athila & 6.32 & 6.88 & 6.73 & 6.02 & 4.96 & 5.56 & 25.69 & 23.54 & 30.33 & 24.4 \\
\hline & & Chromovirideae & 9.6 & 9.57 & 7.97 & 7.40 & 7.35 & 6.17 & 7.11 & 6.63 & 7.49 & 6.97 \\
\hline & & Ogre-Tat & 12.61 & 12.03 & 8.65 & 8.40 & 6.76 & 4.22 & 5.10 & 5.20 & 5.83 & 6.68 \\
\hline & & Total Tyз/Gypsy & 28.53 & 28.48 & 23.35 & 21.82 & 19.07 & 15.95 & 37.90 & 35.37 & 43.65 & 38.05 \\
\hline Unclassified LTR elements & & & 5.51 & 5.15 & 6.35 & 4.43 & 7.14 & 5.35 & 4.55 & 4.14 & 5.54 & 5.15 \\
\hline \multirow[t]{4}{*}{ Other } & LINE & & 0.26 & 0.27 & 0.29 & 0.37 & 0.27 & 0.23 & 0.34 & 0.31 & 0.20 & 0.23 \\
\hline & DNA transposons & & 2.35 & 2.16 & 1.95 & 1.81 & 1.44 & 1.45 & 2.38 & 2.25 & 2.08 & 2.15 \\
\hline & Tandem repeats & & 5.52 & 5.53 & 3.41 & 14.63 & 2.55 & 3.63 & 8.67 & 9.86 & 4.20 & 4.99 \\
\hline & rRNA genes & & 1.13 & 1.07 & 0.57 & 0.50 & 0.43 & 0.56 & 1.48 & 2.03 & 1.23 & 2.10 \\
\hline Unclassified repeats & & & 13.79 & 13.94 & 10.82 & 12.76 & 9.39 & 8.29 & 10.04 & 9.86 & 8.51 & 9.02 \\
\hline
\end{tabular}




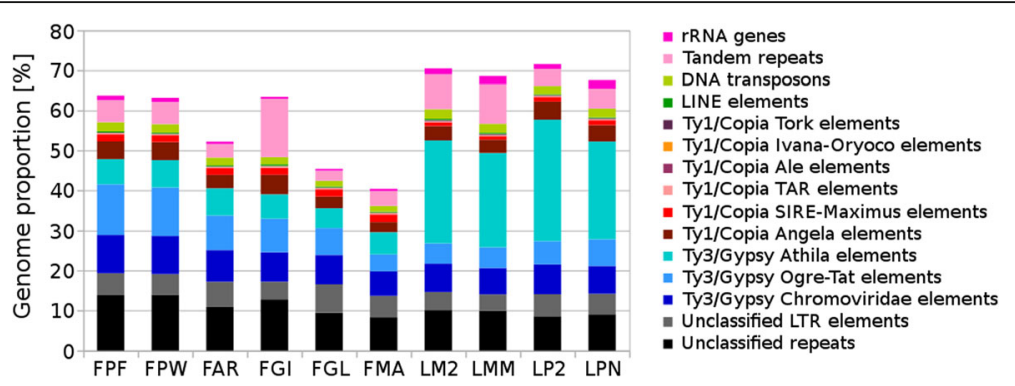

Fig. 3 Genome proportion of the most abundant DNA repeats. The genome proportion of individual repeat types was obtained as a ratio of reads specific to individual repeat types to all reads used for clustering analyses by the RepeatExplorer pipeline. Diploid Festuca pratensis cv. Fure (FPF); tetraploid F. pratensis Cv. Westa (FPW); hexaploid F. arundinacea subsp. arundinacea (FAR); hexaploid F. gigantea (FGI); tetraploid F. glaucescens (FGL); tetraploid F. mairei (FMA); diploid cv. Kuri1 of L. multiflorum (LM2); tetraploid Cv. Mitos of L. multiflorum (LMM); diploid L. perenne (LP2); tetraploid cv. Neptun of L. perenne (LPN)

Lolium species differing in ploidy. The set comprised hexaploids $F$. arundinacea subsp. arundinacea and $F$. gigantea; tetraploids F. glaucescens and F. mairei; and artificial autotetraploids $F$. pratensis cv. Westa, L. multiflorum cv. Mitos, and L. perenne cv. Neptun developed in breeding programs. We estimated nuclear DNA amounts using flow cytometry, and a test of normality confirmed that the data set had a normal distribution. Our results suggest possible genome changes in hexaploid $F$. arundinacea and tetraploid ryegrasses compared to their probable progenitors. Although the differences in the $1 \mathrm{Cx}$ size of natural polyploid $F$. arundinacea and its probable parents $(F$. pratensis and $F$. glaucescens) are small, they are statistically significant $(P<0.01)$. The same is true for tetraploid ryegrass cultivars obtained after polyploidization. Genome downsizing was detected in the case of $F$. arundinacea ( $2 \%$ difference between expected and estimated values) and tetraploid $L$. perenne ( $\sim 1 \%$ decrease). In the tetraploid cultivar of L. multiflorum, a slight increase in genome size $(\sim 4 \%)$ was

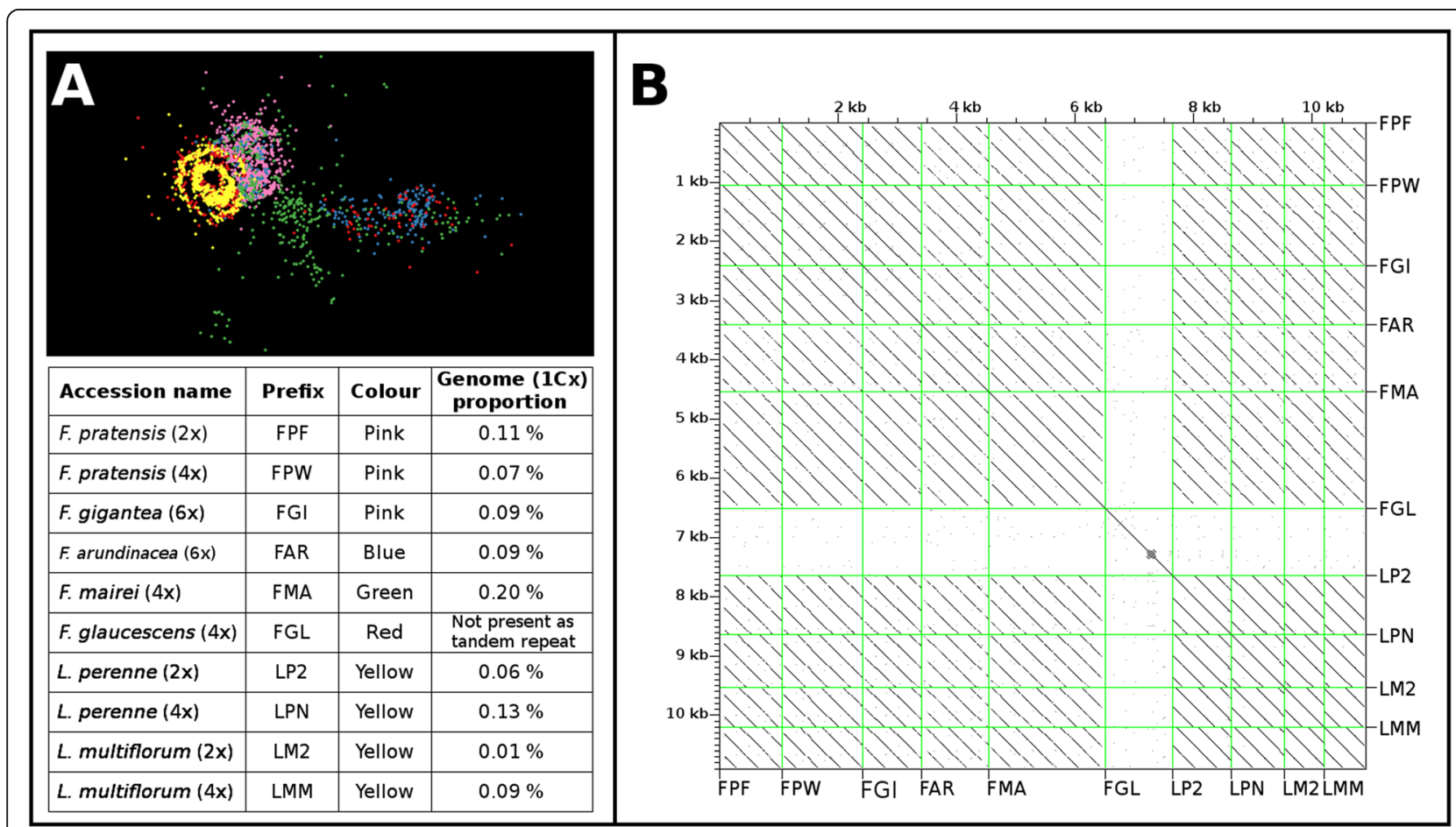

Fig. 4 Tandem organized repeat sequences identified in cluster CL102. a Graphical layout of cluster CL102. b Dot-plot analyses show the presence of homologous tandem organized units (parallel lines) of DNA repeats identified in cluster CL102 in all species except F. glaucescens, in which the assembled sequence contigs did not represent tandem organized sequences 

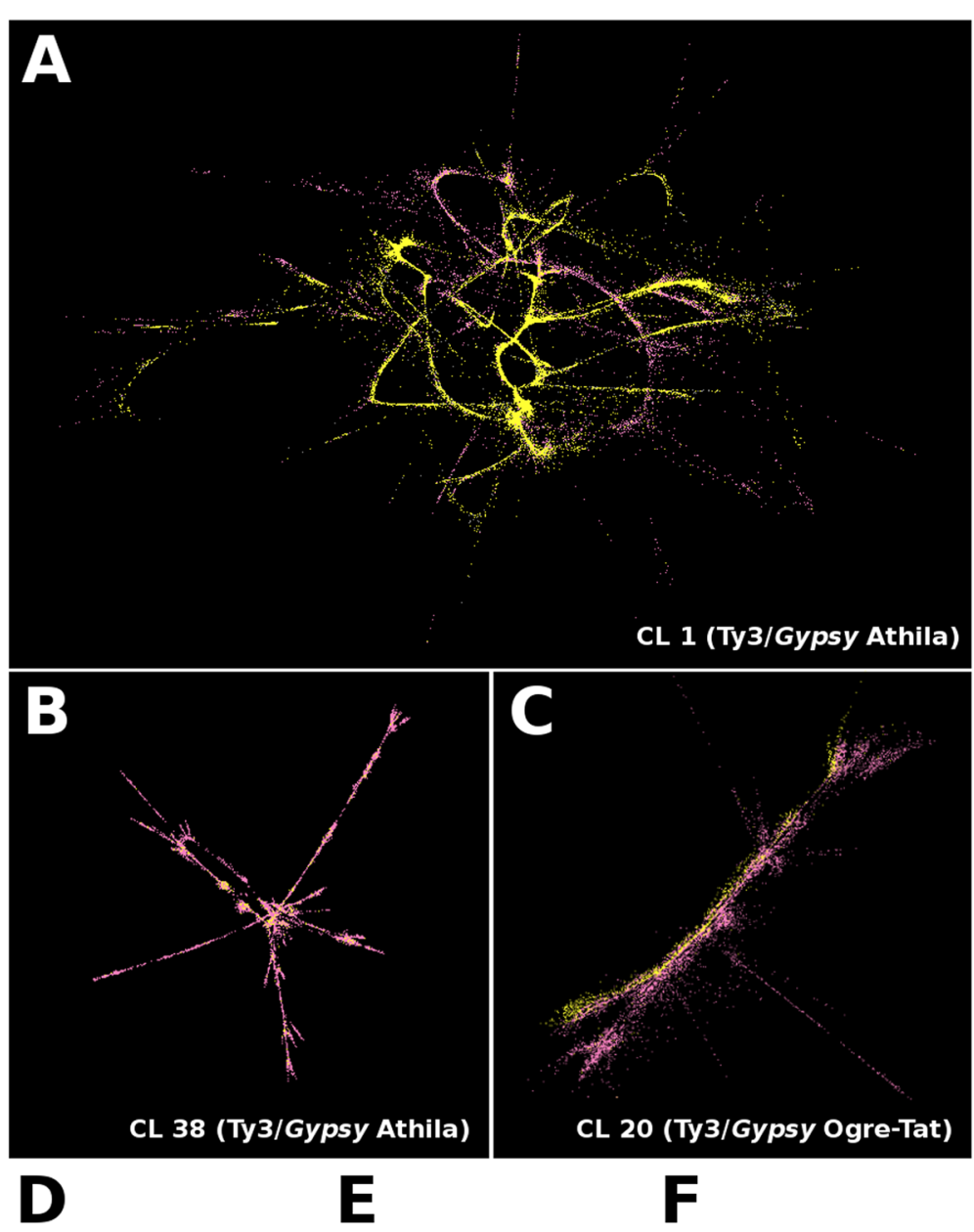

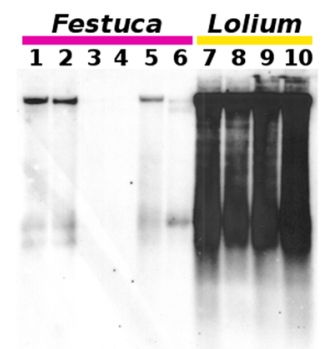

CL 1

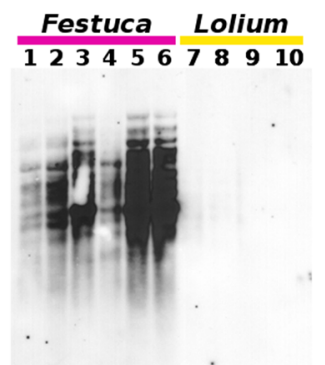

CL 38
$\mathbf{F}$
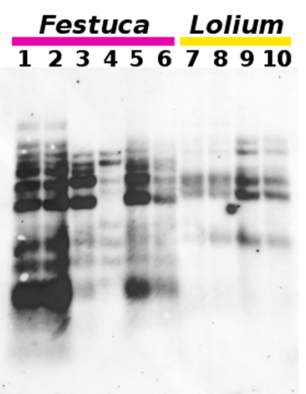

CL 20

Fig. 5 Graphical layouts of selected DNA repeats and their validation by Southern blotting. Graphical layouts were obtained after clustering analyses done by RepeatExplorer. a Cluster CL1. b Cluster CL38 containing the Ty3/gypsy Athila element. c Cluster CL20 containing Ty3/gypsy Ogre/Tat elements. Sequencing reads from Festuca species are in pink, whereas sequencing reads from Lolium species are in yellow. $\mathbf{d}-\mathbf{f}$ Validation of clustering results by Southern hybridization with sequences derived from clusters CL1, CL38, and CL20. Lanes contained genomic DNA digested by Haelll restriction endonuclease. Lane 1: F. pratensis cv. Fure $(2 n=2 x=14)$; lane 2: F. pratensis $\mathrm{cv}$. Westa $(2 n=4 x=28)$; lane 3: $F$. arundinacea subsp. arundinacea $(2 n=6 x=42)$; lane 4: F. gigantea $(2 n=6 x=42)$; lane 5: F. glaucescens $(2 n=4 x=28)$; lane $6: F$. mairei $(2 n=4 x=28)$; lane 7: L. multiflorum Cv. Mitos $(2 n=4 x=28)$; lane 8: L. multiflorum Cv. Kuri1 $(2 n=2 x=14)$; lane 9: L. perenne cv. Neptun $(2 n=4 x=28)$; lane 10: L. perenne GR $3320(2 n=2 x=14)$

detected, corresponding with Kopecký et al. [8]. In the case of tetraploid fescue cultivars obtained after polyploidization, no statistically significant difference in $1 \mathrm{Cx}$ value was found $(P>0.01)$.
DNA retrotransposons are major contributors to the variation in nuclear genomes in plants [24, 46, 47]. Various approaches and tools have been developed to study these important parts of nuclear genomes, one of them 


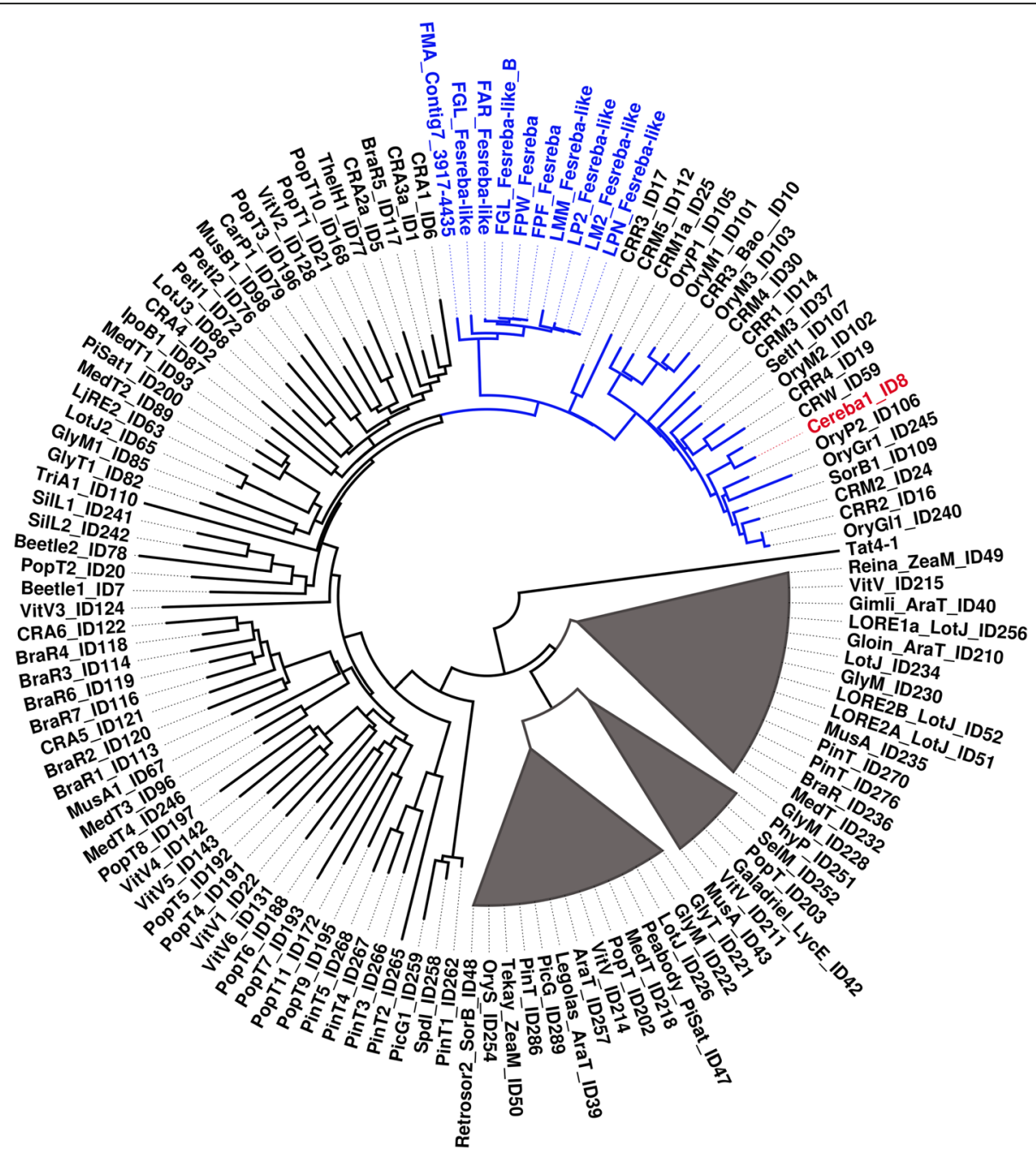

Fig. 6 Phylogenetic tree of Chromoviridae elements. The tree was constructed from a Jukes-Cantor distance matrix of the reverse transcriptase domains of Ty3/gypsy Chromoviridae elements described in Neumann et al. [34] and Fesreba elements identified in the present work with BioNJ implemented in Seaview [5]. The tree was rooted on the Ty3/gypsy/Tat element. The subclade of the Cereba element (in red) and other closely related elements identified in different plant species are labeled in blue. Fesreba elements identified in fescues and ryegrasses are also marked in blue

being RepeatExplorer, which facilitates de novo repeat identification and characterization [42, 48]. The pipeline uses graph-based clustering and analyzes nextgeneration sequencing data to reconstruct and characterize DNA repeats in a particular species or to compare DNA repeat composition in different genotypes $[23,24,49-51]$. The pipeline has been frequently used to reconstruct DNA repeats in diversity studies, to create repeat databases for repeat masking $[19,46,48]$, and to identify tandem organized repeats suitable as probes for molecular cytogenetics $[35,51-53]$.

Our work revealed that Ty3/gypsy elements had the highest impact on genome size in fescues and ryegrasses. Ty3/gypsy elements are also abundant in other Poaceae species, including wheat, rice, maize, and barley $[8$,
54-56]. In barley, about $50 \%$ of the genome is made up of 15 high-copy transposable element (TE) families, with elements of the Angela lineage (Ty1/copia family) being the most abundant and representing almost $14 \%$ of the genome [56]. The Ty3/gypsy superfamily is 1.5 -fold more abundant than the Ty1/copia superfamily [56].

Festuca and Lolium genera comprise closely related complexes of species, and thus a high homology of DNA repeats was observed in this study. The main difference was the copy number. In Lolium species the Ty3/gypsy Athila LTR retroelement accounted for $\sim 25 \%$ of the nuclear genomes, whereas in fescues it accounted for $0.7 \%$ in tetraploids F. glaucescens and F. mairei and for $\sim 6 \%$ in other fescues analyzed. This indicates a burst of Athila LTR element linked with Lolium speciation. 


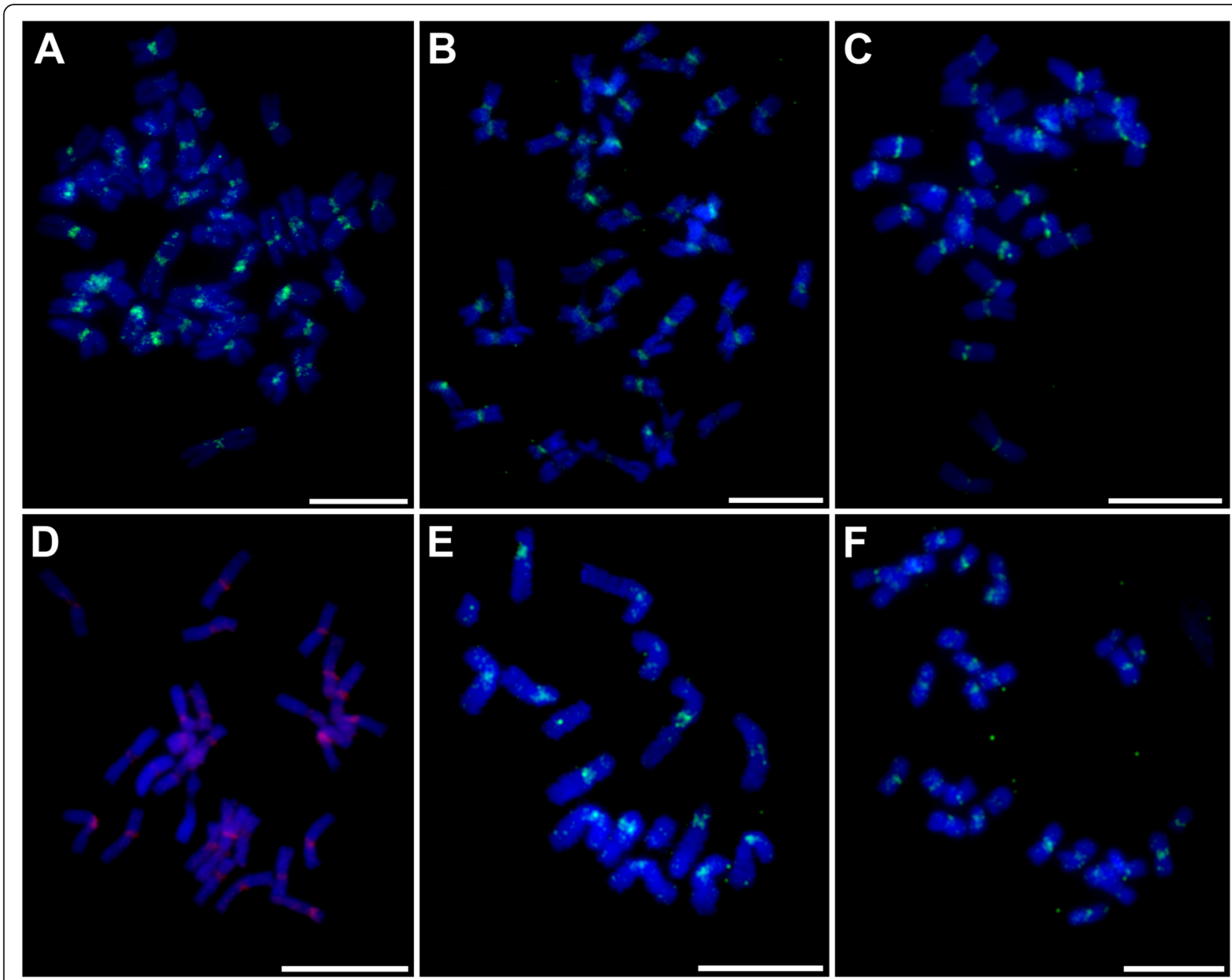

Fig. 7 Localization of the centromeric LTR retrotransposon Fesreba on mitotic metaphase chromosomes. Localization was performed in Festuca and Lolium species with fluorescence in situ hybridization (yellow-green or violet signals) with a probe for the reverse transcriptase domain of the Fesreba element. a F. arundinacea subsp. arundinacea $(2 n=6 x=42)$. b F. gigantea $(2 n=6 x=42)$. c F. mairei $(2 n=4 x=28)$. $\mathbf{d} F$. pratensis $\mathrm{cv}$. Westa $(2 n=4 x=28)$. (E) L. perenne GR $3320(2 n=2 x=14)$. $\mathbf{f}$ L. multiflorum cv. Mitos $(2 n=4 x=28)$. Chromosomes were counterstained with DAPI (blue). The bar corresponds to $10 \mu \mathrm{m}$

Activation and integration of TEs (e.g., as a result of environment change) may lead to a rapid burst of the Athila element in a species-specific manner [46, 47, 57] and impact evolution and speciation $[46,58]$. In some species, a rapid increase in the number of lineagespecific retroelements can also result in significant genome upsizing $[24,58-60]$, which was not observed in the fescues and ryegrasses included in our study.

Species-specific DNA elements identified in this work were represented by tandem organized repeats (Additional file 1: Table S1). Unique tandem repeats are also found in other plant species, and thanks to their genus or species specificity they have been widely used in molecular cytogenetics (e.g., to identify chromosomes using FISH) [61-64]. Tandem repeats originally identified in $F$. pratensis chromosome 4F are useful as probes for FISH to identify individual chromosomes of the species $[18,35]$ and in comparative karyotype analyses of its cultivars. The present work resulted in the identification of other putative tandem organized repeats, either genus or species specific (Additional file 1: Table S1). These observations expand the number of potential cytogenetic markers for comparative karyotyping and identification of chromosomes in other fescue and ryegrass species.

Although the sequencing of $F$. pratensis chromosome 4F revealed a relatively high number of tandem repeats, none of them localized to chromosome centromeric regions $[18,35]$. However, the mapping of other types of 


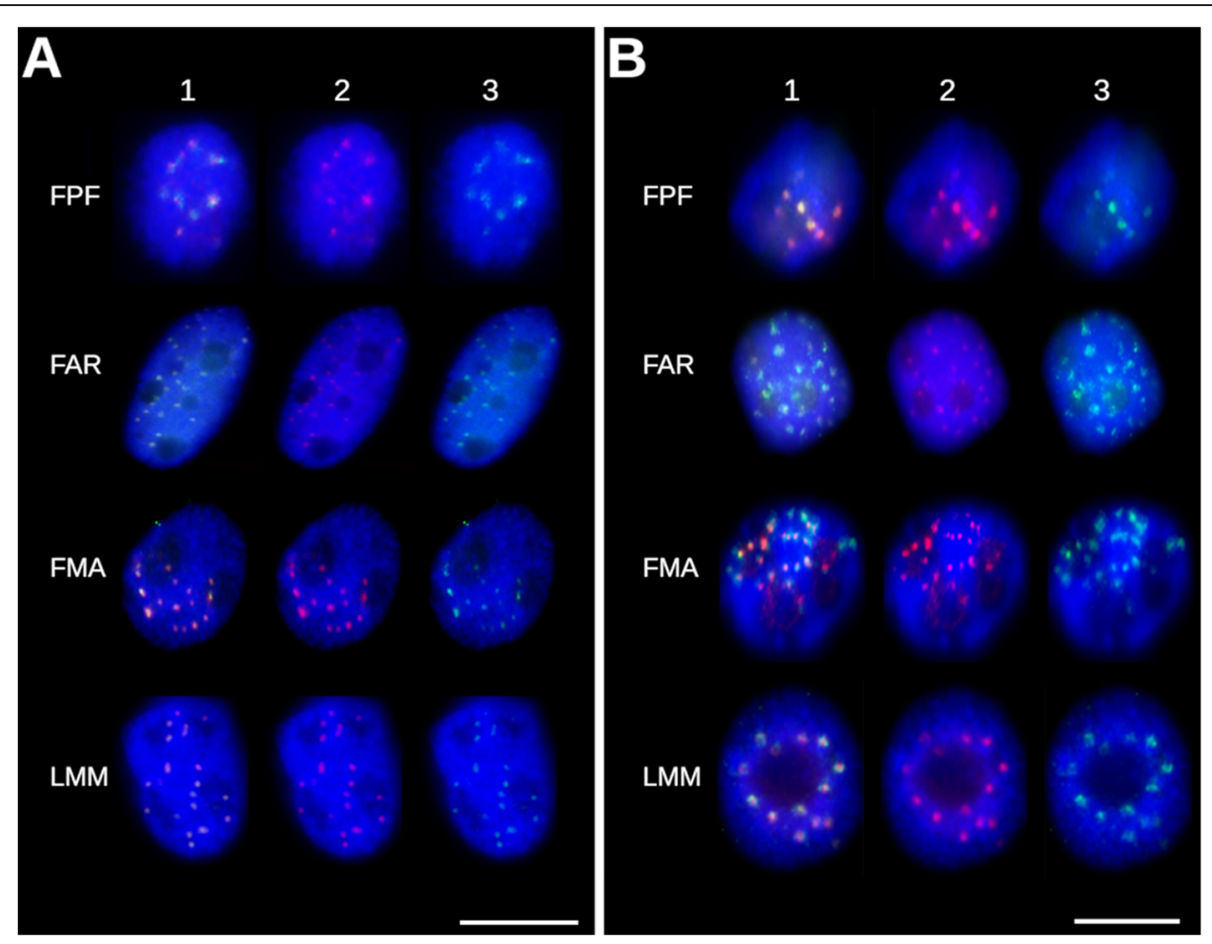

Fig. 8 Co-localization of CENH3 with the Fesreba element in Festuca and Lolium. Combination of immunolocalization of the histone H3 variant CENH3 (red) and FISH on interphase nuclei with probes for: $\mathbf{a}$ the reverse transcriptase (RT) domain (green); and $\mathbf{b}$ the non-coding LTR part of the Fesreba element (green). F. pratensis cv. Fure (FPF); F. arundinacea subsp. arundinacea (FAR); F. mairei (FMA); L. multiflorum cv. Mitos (LMM).

Column 1 shows merged images, column 2 shows CENH3 signals (red), and column 3 shows FISH signals corresponding to the Fesreba element. In all accessions, the signals of CENH3 and FISH probes are overlapping. Nuclei were counterstained with DAPI (blue). The bar corresponds to $10 \mu \mathrm{m}$

DNA repeats on mitotic metaphase chromosomes showed preferential localization of one uncharacterized DNA element CL38 to centromeric regions of F pratensis chromosomes [35]. In this work, the entire DNA element homologous to the CL38 repeat was reconstructed and its nature was clarified. Phylogenetic analyses of its coding domains (Fig. 6) confirmed close relationships with other plant centromeric elements of Ty3/gypsy Chromoviridae lineage, such as Cereba-like elements [43]. Preferential localization of the Cereba element to centromeric regions of barley chromosomes was shown by Hudakova et al. [33], and more complex study of centromere-specific elements belonginging to the lineage of Centromeric retrotransposons in maize (CRM) of the Ty3/gypsy family in larger set of plant species followed [20,34]. These studies imply a role for TEs at the structural level and their impact on centromere structure. Li et al. [65] showed that the Cereba element was strongly associated with the histone $\mathrm{H} 3$ variant $\mathrm{CENH3}$, which plays a role in centromere function. Colocalization of the centromere-specific element Fesreba, reconstructed in this work with histone CENH3 (Fig. 8, Additional file 5: Fig. S3), indicates a role for this element in the function of fescue and ryegrass centromeres as well.

\section{Conclusions}

Partial sequencing of genomes of 10 fescues and ryegrasses revealed various types of retrotransposons as the most abundant repeat. These comparative repeatome analyses increase knowledge of genome organization in fescues and ryegrasses and confirm close relationships between Festuca and Lolium. The most striking difference was observed for the Athila element, which was $\sim 5$ times more abundant in Lolium than Festuca. Highly diverged DNA repeats were represented by tandem organized repeats, which are candidates for species-specific cytogenetic markers. In addition to tandem repeats, other species-specific variants of the majority of repetitive DNA sequences within and between fescues and ryegrasses were identified. A nearly complete LTR element Fesreba was assembled and found to be highly enriched in centromeric and (peri)centromeric chromosome regions in all species. A combination of FISH with a probe for Fesreba and immunostaining with CENH3 antibody showed their co- 
localization and indicated a possible role of Fesreba in centromere function.

\section{Methods}

Plant material

Lolium perenne GR3320 $(2 \mathrm{n}=2 \mathrm{x}=14)$, Festuca arundinacea subsp. arundinacea $(2 \mathrm{n}=6 \mathrm{x}=42)$, Festuca gigantea GR11759 $(2 \mathrm{n}=6 \mathrm{x}=42)$, and Festuca mairei GR610941 $(2 n=4 x=28)$ were obtained as seeds from the Leibniz Institute of Plant Genetics and Crop Plant Research (Gatersleben, Germany) gene bank. Seeds of Festuca pratensis cv. Fure $(2 n=2 x=14)$ were obtained from Dr. Arild Larson (Graminor, Norway). Lolium perenne cv. Neptun $(2 \mathrm{n}=4 \mathrm{x}=28)$, Lolium multiflorum cv. Kuri1 $(2 \mathrm{n}=2 \mathrm{x}=$ 14), and two commercially available cultivars, Lolium. multiflorum cv. Mitos $(2 \mathrm{n}=4 \mathrm{x}=28)$ and Festuca pratensis cv. Westa $(2 n=4 x=28)$, were obtained from Dr. Vladimír Černoch (DLF Seeds, Czech Republic). Festuca glaucescens genotype C-45 $(2 \mathrm{n}=4 \mathrm{x}=28)$ was obtained from Seed Bank, W. Reg. P. I. Station, Pullman, WA.

Seeds of barley (Hordeum vulgare) cv. Morex, rye (Secale cereale) cv. Dánkowskie Diament, and oat (Avena sativa) cv. Atego were obtained from the Leibniz Institute of Plant Genetics and Crop Plant Research gene bank. Seeds of Triticum aestivum cv. Chinese Spring were obtained from Professor Takashi R. Endo (Kyoto University, Japan), and seeds of Aegilops tauschii (lineage AL 8/78; collected by V. Jaaska, University of Estonia, Tartu, Estonia) were provided by Dr. Valárik (Institute of Experimental Botany, Czech Republic). Seeds of pea (Pisum sativum cv. Ctirad) and rye (Secale cereale cv. Dankovske), which served as internal reference standards in flow cytometric analyses, were provided by one of us (JD) and are available at the Institute of Experimental Botany, Czech Republic (https://olomouc.ueb.cas.cz/en/ technology/flow-cytometry-1/reference-dna-standards).

\section{Estimation of nuclear genome size}

Nuclear DNA amounts were determined according to Doležel et al. [66] following the two-step procedure of Otto [67] with modifications. Samples of isolated nuclei stained with propidium iodide were analyzed with a Sysmex CyFlow Space flow cytometer (Sysmex Partec, Münster, Germany) equipped with a $532 \mathrm{~nm}$ laser. Two reference standards were used to estimate DNA amounts in absolute units. Pea (Pisum sativum cv. Ctirad; $2 \mathrm{C}=9.09 \mathrm{pg}$ DNA) [41] served as an internal standard for estimating DNA content in all accessions except F. mairei, for which rye (Secale cereale cv. Dankovske; $2 \mathrm{C}=16.19 \mathrm{pg}$ DNA) [41] was used. Three plants were measured per accession, and each plant was analyzed three times on three different days. At least 5000 nuclei per sample were analyzed. Nuclear amounts were calculated from measurements of individual samples as follows: $2 \mathrm{C}$ nuclear DNA content $(\mathrm{pg})=2 \mathrm{C}$ nuclear DNA content of reference standard $\times$ sample $G_{1}$ peak mean / standard $G_{1}$ peak mean.

Mean nuclear DNA content (2C) was estimated for each plant, with $1 \mathrm{pg}$ DNA equal to $0.978 \times 10^{9} \mathrm{bp}$ [68] The statistical significance of the differences between $1 \mathrm{Cx}$ sizes was determined with one-way ANOVA. Analyses were conducted with NCSS 97 (Statistical Solutions, Cork, Ireland). The significance level $\alpha=0.01$ was used.

\section{Phylogenetic analyses}

Phylogenetic analyses of Loliinae subtribe were based on data published by Catalán et al. [3]. Sequences of ITS regions were downloaded from the NCBI GenBank (GB codes: AF303401-407, AF303410-416, AF303418-419, AF303421-425, AF303428, AF478475-476, AF478478491, AF478493, AF478498-499, AF519975-981, AF5199 83, AF532937, AF532939-948, AF532951-952, AF53295 4, AF532956-960, AF532962-963, AF543514, AF5480 28, AJ240143, AJ240146, AJ240148, AJ240153, AJ24015 5-157, AJ240160, AJ240162, AY099007, AY118087-088, AY118090-092, AY118094-096, AY228161). Brachypodium distachyon (GB code AF303339) was used as an outgroup species. Multiple sequence alignment was done with MAFFT v7.029 (--localpair --maxiterate 1000) [69], and phylograms were constructed with PhyML 3.0 [70] implemented in SeaView v5.0.2 [5]. Approximate likelihood ratio tests [71] were performed to assess branch support. Final phylogenetic trees were depicted with FigTree (http://tree.bio.ed.ac.uk/software/figtree/).

\section{Illumina sequencing and data analyses}

Genomic DNA was isolated with the NucleoSpin PlantII kit (Macherey-Nagel, Düren, Germany) according to the manufacturer's recommendations and used to prepare Illumina libraries with a Nextera ${ }^{\circ}$ DNA Sample Preparation Kit (Illumina, San Diego, CA, USA). Briefly, 50 ng DNA was fragmented, purified, and amplified according to the protocol. The DNA concentration in individual libraries was measured with a Qubit fluorometer, adjusted to an equal molar concentration, and pooled prior to sequencing. DNA sequencing was done with an Illumina MiSeq with either single or paired-end sequencing to produce up to $500 \mathrm{bp}$ reads. Sequence reads were deposited in the Sequence Read Archive (BioProject ID: PRJNA601325, accessions SAMN13866227, SAMN1386 6228, SAMN13866229, SAMN13866230, SAMN138662 31, SAMN13866232, SAMN13866233, SAMN13866234, SAMN13866235, SAMN13866236).

Illumina reads were trimmed for adapters and for quality with the FASTX-Toolkit (-q 20 -p 90; http://hannonlab. cshl.edu/fastx_toolkit/index.html). Detailed characterization of repeat families was performed with a stand-alone version 
of the RepeatExplorer pipeline [37] running on an IBM server with 16 processors, $100 \mathrm{~Gb}$ RAM, and $17 \mathrm{~Tb}$ disk space. In the first step, comparative analyses of repetitive parts of the genomes were performed with the RepeatExplorer pipeline according to Novák et al. [49]. Random data sets represented the same amount of reads $(0.5 \times$ coverage of individual accessions) were used to reconstruct repetitive elements using a graph-based method according Novák et al. [48]. The RepeatExplorer pipeline led to the characterization of assembled sequences using different tools (e.g., BLASTN and BLASTX, phylogenetic analysis) $[37,48]$. Tandem organized repeats were identified with Dotter [72].

In the second step, the RepeatExplorer pipeline was applied to a merged data set containing all species marked by specific prefixes to perform comparative analyses [49]. The results of the clustering were then used to create repetitive databases. Databases of Illumina reads were deposited in the Sequence Read Archive (accessions: SRX7566047-SRX7566056). Assembled contigs from different types of repetitive DNA elements are publicly available online (https://olomouc.ueb.cas.cz/en/content/dna-repeats) and in the Dryad digital repository (doi:https://doi.org/10.5061/dryad.xksn02vch).

\section{Southern hybridization}

Genomic DNA corresponding to $3 \times 10^{6}$ copies of a $1 \mathrm{Cx}$ nuclear genome was digested by HaeIII enzyme (New England Biolabs, Ipswich, MA, USA). DNA fragments were size-fractionated by electrophoresis in $1.2 \%$ agarose gel and then transferred onto Hybond ${ }^{\mathrm{m}} \mathrm{N}+$ nylon membranes (GE Healthcare, Chicago, IL, USA). Probes were prepared with $F$. pratensis genomic DNA as a template and polymerase chain reaction (PCR) with biotin-labeled dUTP (Roche, Mannheim, Germany) and specific primers (Additional file 6: Table S3, Additional file 7: Fig. S4). Southern hybridization was performed at $68^{\circ} \mathrm{C}$ overnight, and hybridization signals were detected with a Chemiluminescent Nucleic Acid Module (Thermo Fisher Scientific, Waltham, MA, USA) according to the manufacturer's recommendations with $90 \%$ stringency. Hybridization signals were visualized with chemiluminiscent substrate on Medical X-Ray Film Blue (Agfa Healthcare, Mortsel, Belgium).

\section{ddPCR}

Based on the assembled DNA contigs from the Fesreba retrotransposon, two restriction endonucleases with unique restriction sites in the retrotransposon ( $\mathrm{HpaI}$ and HpaII) were identified and used for further analyses. Briefly, $3 \mu \mathrm{g}$ genomic DNA was digested according to the manufacturer's recommendations (Bio-Rad Laboratories, Hercules, CA, USA) and then diluted 1000-fold to reach a starter concentration of $0.06 \mathrm{ng} / \mu \mathrm{l}$. ddPCR was performed on a QX200 Droplet Digital PCR machine (Bio-Rad Laboratories) following the manufacturer's recommendations with EvaGreen Supermix (Bio-Rad Laboratories), template DNA, and specific primers for Fesreba (Additional file 6: Table S3). Three independent replicates were performed for every accession analyzed.

\section{Cytogenetic mapping and immunostaining}

Cytogenetic mapping of selected repeats was done by FISH on mitotic metaphase plates. Chromosome spreads were prepared according to Křivánková et al. [35], and immunostaining was performed according to Neumann et al. [73]. Root tips were collected in ice water for $28 \mathrm{~h}$; washed in LB01 buffer [74]; fixed in 3.7\% formaldehyde for 25 min; and digested using $2 \%$ cellulose, $2 \%$ pectinase, and $2 \%$ cytohelicase in $1 \times$ phosphate-buffered saline (PBS) for $90 \mathrm{~min}$ at $37^{\circ} \mathrm{C}$. After the coverslip was removed, the preparations were washed in $1 \times$ PBS and then in PBSTriton buffer ( $1 \times$ PBS, $0.5 \%$ Triton X-100, $\mathrm{pH} 7.4$ ) for 25 min and then again in $1 \times$ PBS. For incubation with antigrass CENH3 primary antibody [75], the slides were washed in PBS-Tween buffer ( $1 \times$ PBS, $0.1 \%$ Tween 20 , $\mathrm{pH} 7.4$ ) for $25 \mathrm{~min}$ and then incubated with anti-grass CENH3 primary antibody (diluted 1:200 in PBS-Tween) overnight at $4{ }^{\circ} \mathrm{C}$. The next day the slides were washed in $1 \times$ PBS, CENH3 antibody was detected using the antiRabbit Alexa Fluor 546 secondary antibody (Thermo Fisher Scientific/Invitrogen) diluted 1:250 in PBS-Tween buffer for $1 \mathrm{~h}$ at room temperature, and washed $1 \times$ PBS. Before FISH, immunofluorescent signals were stabilized with ethanol:acetic acid (3:1) fixative and 3.7\% formaldehyde for $10 \mathrm{~min}$ at room temperature. FISH was performed after three washes in $1 \times$ PBS.

Probes for FISH, derived from the RT and LTR regions of the Fesreba element, were labeled with digoxigenin-11dUTP or biotin-16-dUTP (Roche Applied Science) using PCR with specific primers (Additional file 6: Table S3). FISH and detection of hybridization sites were performed according to Křivánková et al. [35]. The chromosomes were counterstained with 4',6-diamidino-2-phenylindole (DAPI) and mounted in Vectashield (Vector Laboratories). The slides were examined with an Axio Imager.Z2 microscope (Carl Zeiss, Oberkochen, Germany) equipped with a Cool Cube 1 (Metasystems, Altlussheim, Germany) camera, and images were prepared with ISIS 5.4.7 (Metasystems). Final adjustments were made to figures in Adobe Photoshop 12.0.

\section{Supplementary information}

Supplementary information accompanies this paper at https://doi.org/10. 1186/s12870-020-02495-0.

Additional file 1: Table S1. List of clusters containing putative tandem repeats identified in Festuca and Lolium. 
Additional file 2: Fig. S1. Southern blots for the RT domain and noncoding LTR part of the Fesreba element. Southern blots were made with probes for the reverse transcriptase domain (A) and non-coding LTR region (B) of the Fesreba element. Lanes contained genomic DNA digested by Haelll restriction endonuclease. Lane 1: diploid F. pratensis cv. Fure; lane 2: tetraploid $F$. pratensis cv. Westa; lane 3: hexaploid F. arundinacea subsp. arundinacea; lane 4: hexaploid F. gigantea; lane 5: tetraploid F. glaucescens; lane 6: tetraploid F. mairei; lane 7: tetraploid L. multiflorum cV. Mitos; lane 8: diploid L. multiflorum cv. Kuri1; lane 9: tetraploid L. perenne Cv. Neptun; lane 10: diploid L. perenne.

Additional file 3: Table S2. Representation of the RT domain and noncoding part of the LTR region of the Fesreba element estimated by ddPCR. Copy numbers of the reverse transcriptase (RT) domain and noncoding part of the LTR region of the Fesreba element were estimated with droplet digital PCR. Values are averages of three independent experiments with standard deviations.

Additional file 4: Fig. S2. Localization of the centromeric LTR retrotransposon Fesreba on mitotic chromosomes with fluorescence in situ hybridization. Mitotic metaphase plates were hybridized with a probe for the reverse transcriptase domain of the Fesreba element $(A, C, E, G, I)$ and with a combination of probes for the non-coding LTR part of the Fesreba element and $45 \mathrm{~S}$ rDNA, which served as control $(B, D, F, H, J)$. (A, B) Avena sativa cv. Atego $(2 \mathrm{n}=2 \mathrm{x}=14)$. (C, D) Secale cereale cv. Dánkowskie Diament $(2 n=2 x=14)$. $(E, F)$ Hordeum vulgare $c v$. Morex $(2 n=2 x=$ 14). $(G, H)$ Triticum aestivum cv. Chinese Spring $(2 n=6 x=42)$. (I, J) Aegilops tauschii $(2 n=2 x=14)$. Signals corresponding to 45 S rDNA loci are marked by arrows. Hybridization signals of a probe for the LTR region of the Fesreba element were absent in all related species $(D, F, H, J)$ except A. sativa (B). Chromosomes were counterstained with DAPI (blue). The bar corresponds to $10 \mu \mathrm{m}$.

Additional file 5: Fig. S3. Co-localization of CENH3 with the Fesreba element in three Festuca and three Lolium species. Immunolocalization of the histone $\mathrm{H} 3$ variant CENH3 (red) and FISH with probes for the reverse transcriptase (RT) domain and non-coding LTR part of the Fesreba element (green). F. gigantea (FGl); F. glaucescens (FGL); F. pratensis Westa (FPW); L. multiflorum Lm2 (LM2); L. perenne Neptun (LP2); L. perenne (LPN) Column 1 shows merged images, column 2 shows CENH3 signals (red), and column 3 shows FISH signals corresponding to the Fesreba element. In all accessions, the signals of CENH3 and FISH probes are overlapping. Nuclei were counterstained with DAPI (blue). The bar corresponds to $10 \mu \mathrm{m}$.

Additional file 6: Table S3. Primers used for PCR amplification of DNA repeats.

Additional file 7: Fig. S4. Original images of Southern hybridization depicted in Fig. 5 and Additional file 2: Fig. S1, respectively. Original images of Southern hybridization with sequences derived from cluster CL1 (A), cluster CL38 (B), and cluster CL20 (C) and with sequences for the reverse transcriptase domain (D) and non-coding LTR region (E) of the Fesreba element. Lanes contained genomic DNA digested by Haelll restriction endonuclease. Lane 1: diploid F. pratensis cv. Fure; lane 2: tetraploid F. pratensis cv. Westa; lane 3: hexaploid F. arundinacea subsp. arundinacea; lane 4: hexaploid F. gigantea; lane 5: tetraploid F. glaucescens; lane 6: tetraploid F. mairei; lane 7: tetraploid L. multiflorum cv. Mitos; lane 8: diploid L. multiflorum CV. Kuri1; lane 9: tetraploid L. perenne CV. Neptun; lane 10: diploid L. perenne.

\section{Abbreviations}

1C: Holoploid genome; 1CX: Monoploid genome; 2C: Nuclear DNA amount in G1 nucleus prior to DNA replication; 4F: Chromosome 4 of Festuca pratensis cv. Fure; bp: Base pairs; CENH3: Centromeric histone H3; CL: Cluster of orthologous sequences obtained by RepeatExplorer analysis;

CRM: Centromeric retrotransposon in maize; Cy3: Cy3 fluorescent dye;

DAPI: 4',6-diamidino-2-phenylindole; ddPCR: Droplet digital polymerase chain reaction; DNA: Deoxyribonucleic acid; dUTP: 2'-deoxyuridine 5'-triphosphate; FAR: Festuca arundinacea Schreb. subsp. arundinacea; FGI: Festuca gigantea $\mathrm{L}$. GR11759; FGL: Festuca arundinacea Schreb. subsp. glaucescens;

FISH: Fluorescence in situ hybridization; FITC: Fluorescein isothiocyanate; FMA: Festuca mairei GR610941; FPF: Festuca pratensis Huds. cv. Fure: FPW: Festuca pratensis Huds. cv. Westa; G1: G1 phase of cell cycle;
Gbp: Gigabase pairs; ID: Identity number; LINE: Long interspersed nuclear element; LM2: Lolium multiflorum cv. Kuri1; LMM: Lolium multiflorum Lam. Cv. Mitos; LP2: Lolium perenne L. GR3320; LPN: Lolium perenne L. cv. Neptun; LTR: Long terminal repeat; $\mu$ l: Microliter; NCBI: National Center for Biotechnology Information; ng: Nanogram; PBS: Phosphate-buffered saline; PCR: Polymerase chain reaction; pg: Picogram; pH: Potential of hydrogen; rDNA: Ribosomal DNA, DNA with ribosomal RNA genes; rRNA: Ribosomal RNA, RNA involved in structure of ribosomes and proteosynthesis; RT: Reverse transcriptase; SSC: Saline sodium citrate; TE: Transposable element

\section{Acknowledgments}

We thank H. Tvardíková and E. Jahnová for technical support, P. Navrátil for technological support, and V. Černoch (DLF Seeds, Czech Republic) and M. Valárik (Institute of Experimental Botany, Czech Republic) for providing plant material.

\section{Authors' contributions}

JZ prepared DNA for sequencing, analyzed Illumina sequence data, and performed DNA repeat reconstruction and further analyses of repeats. JC and DK performed flow cytometric estimation of genome size; $\mathrm{KH}$ and BJT performed Illumina sequencing; and JZ, DK, VK, and AN performed cytogenetic analyses, including immuno-FISH. RS and JZ performed ddPCR and interpreted the results. EH and JD made intellectual contributions to the study and revised the manuscript critically for important intellectual content. All authors read and approved the final manuscript.

\section{Funding}

This work was supported by the ERDF project "Plants as a Tool for Sustainable Global Development" (No. CZ.02.1.01/0.0/0.0/16_019/0000827). Computational support was provided by the National Grid Infrastructure MetaCentrum (Grant No. LM2010005 under the program Projects of Large Infrastructure for Research, Development, and Innovations). The funders had no role in the study design, data analysis and interpretation, or writing of the manuscript.

\section{Availability of data and materials}

All relevant supporting data sets are included in the article and its additional files. The data sets supporting the conclusions in this article are available in the Sequence Read Archive (accessions: SRX7566047-SRX7566056) and Dryad repository (doi:https://doi.org/10.5061/dryad.xksn02vch; https:// datadryad.org/stash/share/8pm4qJ41tIJaXNd7EYkan125DKR-Vi8BINbF4 HSobVg).

\section{Ethics approval and consent to participate}

Not applicable.

\section{Consent for publication}

Not applicable.

\section{Competing interests}

The authors declare that they have no competing interests.

\section{Author details}

${ }^{1}$ Institute of Experimental Botany, Czech Academy of Sciences, Centre of the Region Haná for Biotechnological and Agricultural Research, Šlechtitelů 31, CZ-77900 Olomouc, Czech Republic. ${ }^{2}$ Centro de Genómica Nutricional Agroacuícola, Las Heras 350, Temuco, Chile.

Received: 16 January 2020 Accepted: 15 June 2020

Published online: 17 June 2020

\section{References}

1. Inda LA, Segarra-Moragues JG, Müller J, Peterson PM, Catalán P. Dated historical biogeography of the temperate Loliinae (Poaceae, Pooideae) grasses in the northern and southern hemispheres. Mol Phylogenet Evol. 2008;46:932-57. https://doi.org/10.1016/j.ympev.2007.11.022.

2. Watson L, Dawitz MJ. The grass genera of the world. Wallingford: C. A. B. International; 1992.

3. Catalán P, Torrecilla P, López Rodriguez JA, Olmstead RG. Phylogeny of the festucoid grasses of subtribe Loliinae and allies (Poaea, Pooideae) inferred 
from ITS and trnL-F sequences. Mol Phylogenet Evol. 2004;31(2):517-41. https://doi.org/10.1016/j.ympev.2003.08.025.

4. Torrecilla P, Catalán P. Phylogeny of broad-leaved and fine-leaved Festuca lineages (Poaceae) based on nuclear ITS sequences. Syst Bot. 2002;27(2):241-52. https://doi.org/10.1043/0363-6445-27.2.241.

5. Gouy M, Guindon S, Gascuel O. SeaView version 4: a multiplatform graphical user interface for sequence alignment and phylogenetic tree building. Mol Biol Evol. 2010;27(2):221-4. https://doi.org/10.1093/molbev/ msp259.

6. Soreng RJ, Peterson PM, Romaschenko K, Davidse G, Zuloaga FO, Judziewicz EJ, et al. A worldwide phylogenetic classification of the Poaceae (Gramineae). J Syst Evol. 2015;53:117-37. https://doi.org/10.1111/jse.12150.

7. Šmarda P, Bureš P, Horová L, Foggi B, Rossi G. Genome size and GC content evolution of Festuca: ancestral expansion and subsequent reduction. Ann Bot. 2008;101 (3):421-33. https://doi.org/10.1093/aob/mcm307.

8. Kopecký D, Havránková M, Loureiro J, Castro S, Lukaszewski AJ, Bartoš J, et al. Physical distribution of homoeologous recombination in individual chromosomes of Festuca pratensis in Lolium multiflorum. Cytogenet Genome Res. 2010;129(1-3):162-72. https://doi.org/10.1159/000313379.

9. Kopecký D, Lukaszewski AJ, Doležel J. Cytogenetics of Festulolium (Festuca $x$ Lolium hybrids). Cytogenet Genome Res. 2008;120(3-4):370-83. https://doi. org/10.1159/000121086.

10. Loureiro J, Kopecký D, Castro S, Santos C, Silveira P. Flow cytometric and cytogenetic analyses of Iberian Peninsula Festuca spp. Plant Syst Evol. 2007; 269:89-105. https://doi.org/10.1007/s00606-007-0564-8.

11. Hand ML, Cogan NO, Stewart AV, Forster JW. Evolutionary history of tall fescue morphotypes inferred from molecular phylogenetics of the LoliumFestuca species complex. BMC Evol Biol. 2010;10:303. https://doi.org/10. 1186/1471-2148-10-303.

12. Humphreys J, Harper JA, Armstead IP, Humhreys MW. Introgressionmapping of genes for drought resistance transferred from Festuca arundinaceae var. glaucescens into Lolium multiflorum. Theor Appl Genet. 2005;110:579-87. https://doi.org/10.1007/s00122-004-1879-2.

13. Kopecký D, Bartoš J, Christelová P, Černoch V, Kilian A, Doležel J. Genomic constitution of Festuca $\times$ Lolium hybrids revealed by the DArTFest array. Theor Appl Genet. 2011;122(2):355-63. https://doi.org/10.1007/s00122-0101451-1.

14. Kosmala A, Zwierzykowski Z, Gasior D, Rapacz M, Zwierzykowska E, Humphreys MW. GISH/FISH mapping of genes for freezing tolerance transferred from Festuca pratensis to Lolium multiflorum. Heredity. 2006;96: 243-51. https://doi.org/10.1038/sj.hdy.6800787.

15. Ezquerro-López D, Kopecký D, Inda Luis Á. Cytogenetic relationships within the Maghrebian clade of Festuca subgen. Schedonorus (Poaceae), using flow cytometry and FISH. Anales del Jardín Botánico de Madrid. 2017;74(1):e052. doi:https://doi.org/10.3989/ajbm.2455.

16. Czaban A, Sharma S, Byrne SL, Spannagl M, Mayer KF, Asp T. Comparative transcriptome analysis within the Lolium/Festuca species complex reveals high sequence conservation. BMC Genomics. 2015;16(1):249. https://doi.org/ 10.1186/s12864-015-1447-y.

17. Byrne SL, Nagy I, Pfeifer M, Armstead I, Swain S, Studer B, et al. A syntenybased draft genome sequence of the forage grass Lolium perenne. Plant J. 2015;84:816-26. https://doi.org/10.1111/tpj.13037.

18. Kopecký D, Martis M, Číhalíková J, Hřibová E, Vrána J, Bartoš J, et al. Flow sorting and sequencing meadow fescue chromosome 4F. Plant Physiol. 2013;163(3):1323-37. https://doi.org/10.1104/pp.113.224105.

19. SanMiguel $P$, Bennetzen JL. Evidence that a recent increase in maize genome size was caused by the massive amplification of intergene retrotransposons. Ann Bot. 1998;82(1):37-44. https://doi.org/10.1006/anbo. 1998.0746

20. Wicker T, Gundlach H, Spannagl M, Uauy C, Borrill P, Ramírez-González RH, et al. Impact of transposable elements on genome structure and evolution in bread wheat. Genome Biol. 2018;19(1):103. https://doi.org/10.1186/ s13059-018-1479-0.

21. Hřibová E, Neumann P, Matsumoto T, Roux N, Macas J, Doležel J. Repetitive part of the banana (Musa acuminata) genome investigated by low-depth 454 sequencing. BMC Plant Biol. 2010;10:204. https://doi.org/10.1186/14712229-10-204.

22. Piednoel M, Aberer AJ, Schneeweiss GM, Macas J, Novák P, Gundlach H, et al. Next-generation sequencing reveals the impact of repetitive DNA across phylogenetically closely related genomes of Orobanchaceae. Mol Biol Evol. 2012;29(11):3601-11. https://doi.org/10.1093/molbev/mss168.
23. Dodsworth S, Chase MW, Kelly LJ, Leitch IJ, Macas J, Novák P, et al. Genomic repeat abundances contain phylogenetic signal. Syst Biol. 2015;64(1):112-26. https://doi.org/10.1093/sysbio/syu080.

24. Macas J, Novák P, Pellicer J, Čížková J, Kobližžková A, Neumann P, et al. In depth characterization of repetitive DNA in 23 plant genomes reveals sources of genome size variation in the vegume vribe Fabeae. PLoS One. 2015;10(11):e0143424. https://doi.org/10.1371/journal.pone.0143424.

25. Leitch IJ, Bennett MD. Genome downsizing in polyploid plants. Biol J Linn Soc. 2004;82:651-63. https://doi.org/10.1111/j.1095-8312.2004.00349.x.

26. Mandáková T, Joly S, Krzywinski M, Mummenhoff K, Lysák MA. Fast diploidization in close mesopolyploid relatives of Arabidopsis. Plant Cell. 2010;22(7):2277-90. https://doi.org/10.1105/tpc.110.074526.

27. Renny-Byfield S, Kovarík A, Kelly L, Macas J, Novák P, Chase MW, et al. Diploidization and genome size change in allopolyploids is associated with differential dynamics of low- and high-copy sequences. Plant J. 2013;74(5): 829-39. https://doi.org/10.1111/tpj.12168.

28. Ananiev EV, Phillips RL, Rines HW. Chromosome-specific molecular organization of maize (Zea mays L.) centromeric regions. Proc. Natl Acad. Sci. USA. 1998:95:13073-8. https://doi.org/10.1073/pnas.95.22.13073.

29. Kumekawa N, Hosouchi T, Tsuruoka H, Kotani H. The size and sequence organization of the centromeric region of Arabidopsis thaliana chromosome 4. DNA Res. 2001;8:285-90. https://doi.org/10.1093/dnares/8.6.285.

30. Li Y, Zuo S, Zhang Z, Li Z, Han J, Chu Z, et al. Centromeric DNA characterization in the model grass Brachypodium distachyon provides insights on the evolution of the genus. Plant J. 2018;93(6):1088-101. https:/ doi.org/10.1111/tpj.13832.

31. Cheng Z, Dong F, Langdon T, Ouyang S, Buell CR, Gu M, et al. Functional rice centromeres are marked by a satellite repeat and a centromere-specific retrotransposon. Plant Cell. 2002;14(8):1691-704. https://doi.org/10.1105/tpc. 003079.

32. Gorinšek B, Gubenšek F, Kordiš D. Phylogenomic analysis of chromoviruses. Cytogenet Genome Res. 2005;110(1-4):543-52. https://doi.org/10.1159/ 00008487

33. Hudakova S, Michalek W, Presting GG, ten Hoopen R, dos Santos K, Jasencakova Z, et al. Sequence organization of barley centromeres. Nucleic Acids Res. 2001;29:5029-35. https://doi.org/10.1093/nar/29.24.5029.

34. Neumann P, Navrátilová A, Kobližková A, Kejnovský E, Hřibová E, Hobza R, et al. Plant centromeric retrotransposons: a structural and cytogenetic perspective. Mob DNA. 2011;2(1):4. https://doi.org/10.1186/1759-8753-2-4.

35. Krrivánková A, Kopecký D, Stočes Š, Doležel J, Hrribová E. Repetitive DNA: A versatile tool for karyotyping in Festuca pratensis Huds. Cytogenet Genome Res 2017;151(2):96-105. doi:https://doi.org/10.1159/000462915.

36. Paux E, Roger D, Badaeva E, Gay G, Bernard M, Sourdille P, et al. Characterizing the composition and evolution of homoeologous genomes in hexaploid wheat through BAC-end sequencing on chromosome 3B. Plant J. 2006;48(3):463-74. https://doi.org/10.1111/j.1365-313X.2006.02891.X.

37. Fu K, Guo Z, Zhang X, Fan Y, Wu W, Li D, et al. Insight into the genetic variability analysis and cultivar identification of tall fescue by using SSR markers. Hereditas. 2016;153:9. https://doi.org/10.1186/s41065-016-0013-1.

38. Koo DH, Nam YW, Choi D, Bang JW, de Jong H, Hur Y. Molecular cytogenetic mapping of Cucumis sativus and C. melo using highly repetitive DNA sequences. Chromosom Res. 2010;18(3):325-36. https://doi.org/10. 1007/s10577-010-9116-0.

39. Mehrotra S, Goyal V. Repetitive sequences in plant nuclear DNA: types, distribution, evolution and function. Genom Proteom Bioinf. 2014;12(4):16471. https://doi.org/10.1016/j.gpb.2014.07.003

40. Nybom H, Weising K1, Rotter B. DNA fingerprinting in botany: past, present, future. Investig Genet. 2014;5(1):1. doi:https://doi.org/10.1186/2041-2223-5-1.

41. Doležel J, Greilhuber J, Lucretti S, Meister A, Lysák MA, Nardi L, et al. Plant genome size estimation by flow Cytometry: inter-laboratory comparison. Ann Bot. 1998:82:17-26. https://doi.org/10.1093/aob/mci005.

42. Novák P, Neumann P, Pech J, Steinhaisl J, Macas J. RepeatExplorer: a galaxybased web server for genome-wide characterization of eukaryotic repetitive elements from next-generation sequence reads. Bioinformatics. 2013;29(6): 792-3. https://doi.org/10.1093/bioinformatics/btt054.

43. Presting GG, Malysheva L, Fuchs J, Schubert I. A Ty3/gypsy retrotransposon-like sequence localizes to the centromeric regions of cereal chromosomes. Plant J. 1998;16(6):721-8. https://doi.org/10.1046/j. 1362-313x.1998.00341.x.

44. Sanei M, Pickering R, Kumke K, Nasuda S, Houben A. Loss of centromeric histone H3 (CENH3) from cetromeres precedes uniparental chromosome 
elimination in interspecific barley hybrids. Proc Natl Acad Sci U S A. 2011; 108:E498-505. https://doi.org/10.1073/pnas.1103190108.

45. Murray BG, De Lange PJ, Ferguson AR. Nuclear DNA variation, chromosome numbers and polyploidy in the endemic and indigenous grass flora of New Zealand. Ann Bot. 2005;96(7):1293-305. https://doi.org/10.1093/aob/mci281.

46. Zhang Q-J, Gao L-I. Rapid and recent evolution of LTR retrotransposons drives rice genome evolution during the speciation of AA-genome Oryza species. G3 (Bethesda). 2017;7(6). doi:https://doi.org/10.1534/g3.116.037572.

47. McCann J, Macas J, Novák P, Stuessy TF, Villasenor JL, Weiss-Schneweiss H. Differential genome size and repetitive DNA evolution in diploid species of Melampodium sect. Melampodium (Asteraceae). Front. Plant Sci. 2020;11:362. https://doi.org/10.3389/fpls.2020.00362.

48. Novák P, Neumann P, Macas J. Graph-based clustering and characterization of repetitive sequences in next-generation sequencing data. BMC Bioinformatics. 2010;11:378. https://doi.org/10.1186/1471-2105-11-378.

49. Novák P, Hrïibová E, Neumann P, Kobližková A, Doležel J, Macas J. Genomewide analysis of repeat diversity across the family Musaceae. PLoS One. 2014;9(6):e98918. https://doi.org/10.1371/journal.pone.0098918.

50. McCann J, Jang TS, Macas J, Schneeweiss GM, Matzke NJ, Novák P, et al. Dating the species network: Allopolyploidy and repetitive DNA evolution in American daisies (Melampodium sect. Melampodium, Asteraceae). Syst Biol. 2018;67(6):1010-24. https://doi.org/10.1093/sysbio/syy024.

51. Renny-Byfield S, Kovařík A, Chester M, Nichols RA, Macas J, Novák P, et al. Independent, rapid and targeted loss of highly repetitive DNA in natural and synthetic allopolyploids of Nicotiana tabacum. PLoS One. 2012;7(5): e36963. https://doi.org/10.1371/journal.pone.0036963.

52. Macas J, Kejnovský E, Neumann P, Novák P, Kobližzová A, Vyskot B. Next generation sequencing-based analysis of repetitive DNA in the model dioecious plant Silene latifolia. PLoS One. 2011;6(11):e27335. https://doi.org/ 10.1371/journal.pone.0027335.

53. Said M, Hřibová E, Danilova TV, Karafiátová M, Čížková J, Friebe B, et al. The Agropyron cristatum karyotype, chromosome structure and cross-genome homoeology as revealed by fluorescence in situ hybridization with tandem repeats and wheat single-gene probes. Theor Appl Genet. 2018;131(10): 2213-27. https://doi.org/10.1007/s00122-018-3148-9.

54. Schnable PS, Ware D, Fulton RS, Stein JC, Wei F, Pasternak S, et al. The B73 maize genome: complexity, diversity, and dynamics. Science. 2009; 326(5956):1112-5. https://doi.org/10.1126/science.1178534.

55. International Rice Genome Sequencing Project, Sasaki T. The map-based sequence of the rice genome. Nature. 2005;436(7052):793-800. https://doi. org/10.1038/nature03895.

56. International Barley Genome Sequencing Consortium, Mayer KF, Waugh R, Brown JW, Schulman A, Langridge P, et al. A physical, genetic and functional sequence assembly of the barley genome. Nature. 2012; 491(7426):711-6. https://doi.org/10.1038/nature11543.

57. Grandbastien MA, Audeon C, Bonnivard E, Casacuberta JM, Chalhoub B, Costa A-PP, et al. Stress activation and genomic impact of Tnt1 retrotransposon in Solanaceae. Cytogenet Genome Res. 2005;1 10(1-4):22941. https://doi.org/10.1159/000084957.

58. Lee J, Waminal NE, Choi HI, Perumal S, Lee SC, Nguyen VB, et al. Rapid amplification of four retrotransposon families promoted speciation and genome size expansion in the genus Panax. Sci Rep. 2017;7(1):17986. https://doi.org/10.1038/s41598-017-08194-5.

59. Bennetzen $J$, Wang $H$. The contribution of transposable elements to the structure, function, and evolution of plant genomes. Annu Rev Plant Biol. 2014;65:505-30. https://doi.org/10.1146/annurev-arplant-050213-035811.

60. Kelly L, Renny-Byfield S, Pellicer J, Macas J, Novák P, Neumann P, et al. Analysis of the giant genomes of Fritillaria (Liliaceae) indicates that a lack of DNA removal characterizes extreme expansion in genome size. New Phytol. 2015;208(2):596-607. https://doi.org/10.1111/nph.13471.

61. Hríbová E, Doleželová M, Town CD, Macas J, Doležel J. Isolation and characterization of the highly repeated fraction of the banana genome. Cytogenet Genome Res. 2007;119(3-4):268-74. https://doi.org/10.1159/ 000112073.

62. Macas J, Neumann P, Navrátilová A. Repetitive DNA In the pea (Pisum sativum L.) genome: comprehensive characterization using 454 sequencing and comparison to soybean and Medicago truncatula. BMC Genomics 2007; 8:427. doi:https://doi.org/10.1186/1471-2164-8-427.

63. Badaeva ED, Amosova AV, Goncharov NP, Macas J, Ruban AS, Grechishnikova IV, et al. A set of cytogenetic markers allows the precise identification of all A-genome chromosomes in diploid and polyploid wheat. Cytogenet Genome Res. 2015;146(1):71-9. https://doi.org/10.1159/ 000433458.

64. Koo DH, Tiwari VK, Hribová E, Doležel J, Friebe B, Gill BS. Molecular cytogenetic mapping of satellite DNA sequences in Aegilops geniculata and wheat. Cytogenet Genome Res. 2016;148(4):314-21. https://doi.org/10.1159/ 000447471.

65. Li B, Choulet F, Heng Y, Hao W, Paux E, Liu Z, et al. Wheat centromeric retrotransposons: the new ones take a major role in centromeric structure. Plant J. 2013;73(6):952-65. https://doi.org/10.1111/tpj.12086.

66. Doležel J, Greilhuber J, Suda J. Estimation of nuclear DNA content in plants using flow cytometry. Nature Prot. 2007;2(9):2233-44. https://doi.org/10. 1038/nprot.2007.310

67. Otto F. DAPI staining of fixed cells for high-resolution flow cytometry of nuclear DNA. In: Crissman HA, Darzynkiewicz Z, editors. Methods in cell biology, Vol 33, pp 105-110. New York: Acad Press; 1990.

68. Doležel J, Bartoš J, Voglmayr H, Greilhuber J. Nuclear DNA content and genome size of trout and human. Cytometry A. 2003;51:127-8. https://doi. org/10.1002/cyto.a.10013.

69. Katoh $\mathrm{K}$, Toh $\mathrm{H}$. Recent developments in the MAFFT multiple sequence alignment program. Brief Bioinf. 2008;9:286-98. https://doi.org/10.1093/bib/ bbn013.

70. Guindon S, Dufayard JF, Lefort V, Anisimova M, Hordijk W, Gascuel O. New algorithms and methods to estimate maximum-likelihood phylogenies: assessing the performance of PhyML 3.0. Syst Biol. 2010;59(3):307-21. https://doi.org/10.1093/sysbio/syq010.

71. Anisimova M, Gascuel O. Approximate likelihood-ratio test for branches: a fast, accurate, and powerful alternative. Syst Biol. 2006;55:539-52. https://doi. org/10.1080/106351506007555453.

72. Sonnhammer EL, Durbin R. A dot-matrix program with dynamic threshold control suited for genomic DNA and protein sequence analysis. Gene. 1995; 167(1-2):GC1-10. https://doi.org/10.1016/0378-1119(95)00714-8.

73. Neumann P, Schubert V, Fuková I, Manning JE, Houben A, Macas J. Epigenetic histone marks of extended meta-polycentric centromeres of Lathyrus and Pisum chromosomes. Front Plant Sci. 2016;7:234. https://doi. org/10.3389/fpls.2016.00234.

74. Doležel J, Binarová P, Lucretti S. Analysis of nuclear DNA content in plant cells by flow cytometry. Biol Plantarum. 1989:31:113-20. https://doi.org/10. 1007/BF02907241.

75. Nagaki K, Cheng Z, Ouyang S, Talbert PB, Kim M, Jones KM, et al. Sequencing of a rice centromere uncovers active genes. Nat Genet. 2004; 36(2):138-45. https://doi.org/10.1038/ng1289.

\section{Publisher's Note}

Springer Nature remains neutral with regard to jurisdictional claims in published maps and institutional affiliations.

\section{Ready to submit your research? Choose BMC and benefit from:}

- fast, convenient online submission

- thorough peer review by experienced researchers in your field

- rapid publication on acceptance

- support for research data, including large and complex data types

- gold Open Access which fosters wider collaboration and increased citations

- maximum visibility for your research: over $100 \mathrm{M}$ website views per year

At BMC, research is always in progress.

Learn more biomedcentral.com/submissions 